Article

\title{
Pentamethylquercetin Improves Adiponectin Expression in Differentiated 3T3-L1 Cells via a Mechanism that Implicates PPAR $\gamma$ together with TNF- $\alpha$ and IL-6
}

\author{
Lei Chen, Ting He, Yi Han, Ji-Zhong Sheng, Si Jin and Man-Wen Jin * \\ Department of Pharmacology, Tongji Medical College, Huazhong University of Science and \\ Technology, Wuhan 430030, China; E-Mail: clean829940@sina.com (L.C.) \\ * Author to whom correspondence should be addressed; E-Mail: tjmwjin@163.com; \\ Tel.: +86-027-62581360; Fax: +86-027-83692608.
}

Received: 18 April 2011; in revised form: 23 June 2011 / Accepted: 1 July 2011 /

Published: 6 July 2011

\begin{abstract}
Adiponectin is an adipocyte-derived hormone that plays a pivotal role in the regulation of lipid and glucose metabolism. Up-regulation of adiponectin expression and production has been shown to benefit for metabolic disorders, including type 2 diabetes, hyperlipidemia, etc. The present study investigated whether the novel polymethoxylated flavonoid pentamethylquercetin (PMQ), a member of polymethoxylated flavonoids family which is present in seabuckthorn (Hippophae L.) would affect adiponectin production in differentiated 3T3-L1 adipocytes. It was found that PMQ increased the adiponectin mRNA and protein expressions in adipocytes in time- and concentration-dependent manners. The PPAR $\gamma$ pathway plays a important roles in this effect of PMQ because blockade of PPAR $\gamma$ by GW9662 eliminates the PMQ-induced up-regulation of adiponectin expression. Furthermore, significant decreases of mRNA expression and secretion of TNF- $\alpha$ and IL-6 were also observed in PMQ-treated cells. Taken together, our study demonstrated that PMQ up-regulates adiponectin expression via a mechanism that implicates PPAR $\gamma$ together with TNF- $\alpha$ and IL- 6 , suggesting that PMQ might be a potential candidate for the treatment of metabolic diseases.
\end{abstract}

Keywords: adiponectin; pentamethylquercetin (PMQ); 3T3-L1 adipocytes; PPAR $\gamma$; TNF- $\alpha$; IL-6 


\section{Introduction}

Obesity or excess accumulation of visceral fat increases the likelihood of various diseases, including heart disease, type 2 diabetes, hyperlipidemia, and osteoarthritis [1]. Numerous works over the past decades have demonstrated that adipose tissue serves not only as the storage site of fat, but also an active endocrine and paracrine organ secreting adipokines, which participate in diverse metabolic processes [2]. Among the adipokines which were secreted by adipocytes, adiponectin has been particularly studied. Adiponectin is an adipocyte-derived hormone that plays a pivotal role in the regulation of lipid and glucose metabolism [3,4]. Physiologically, adiponectin stimulates fatty acid oxidation and enhances insulin-sensitivity of peripheral organs, leading to increase of glucose uptake and fatty acid oxidation in muscles [5,6]. It also exerts protective roles against chronic inflammatory and atherosclerosis [7-10]. Furthermore, several lines of evidence have indicated that plasma concentration of adiponectin is severely decreased in patients with obesity [11], type 2 diabetes, and cardiovascular diseases [12,13]. Considering the important role of adiponectin in energy metabolism, agents that up-regulate adiponectin expression and production may benefit obesity, insulin resistance, type 2 diabetes and other related metabolic diseases.

Accumulated evidence suggests that a high intake of plant foods is associated with lower risk of chronic diseases [14,15]. Recently, the flavonoids, a class of secondary metabolites extensively present in a wide range of plant foods, have received substantial attention by its manifold biological roles. Studies have shown that flavonoids protect tissues against chronic pathologies such as coronary events, cardiovascular disease mortality, and diabetes [15-17]. Compared with flavonoids aglycone, methoxylated flavonoids have higher intestinal absorption and are much more resistant to hepatic metabolism [18]. Furthermore, polymethoxylated flavonoids (PMFs) have been shown to alleviate metabolic disorders. For instance, nobiletin improves lipid and glucose homeostasis and modulates adipokines in fructose-induced insulin resistant hamsters [19]. Results from in vitro experiments also reveal that polymethoxylated flavones positively regulate adiponectin expression and production [20,21].

Polymethoxylated flavonoids have been shown to have better pharmacodynamic and pharmacokinetic properties compared to their polyhydroxylated analogs, however, it is hard to obtain large amounts of PMF from the natural world. Thus, we synthesized pentamethylquercetin (PMQ), a nature polymethoxylated flavonoid present in the common seabuckthorn (Hippophae rhamnoides) [22] and hypothesized that, in addition to myocardial protection effects [23], PMQ could regulate adiponectin expression in 3T3-L1 adipocytes. In order to elucidate its potential mechanisms, we investigated whether $\operatorname{PPAR} \gamma$, a key modulator of adiponectin production, played a role in this effect of PMQ.

\section{Results and Discussion}

\subsection{Structure Confirmation and Identification of Synthetic PMQ}

The chemical structure of PMQ was showed in Figure 1. This structure was confirmed by ${ }^{1} \mathrm{H}-\mathrm{NMR}$ and ${ }^{13} \mathrm{C}-\mathrm{NMR}$ (Table 1) and was concordant with data in previous reports [24,25]. PMQ was quantified via HPLC analysis and the purity of PMQ reaches up to $99.5 \%$. 
Figure 1. Chemical structure of pentamethylquercetin (PMQ).<smiles>COc1cc(OC)c2c(=O)c(O)c(-c3ccc(OC)c(OC)c3)oc2c1</smiles>

Table 1. ${ }^{1} \mathrm{H}-(500 \mathrm{MHz})$ and ${ }^{13} \mathrm{C}-\mathrm{NMR}(125 \mathrm{MHz})$ data of PMQ $\left(\mathrm{CDC}_{13}\right)$.

\begin{tabular}{|c|c|c|}
\hline Position & $\begin{array}{c}{ }^{13} \mathrm{C}-\mathrm{NMR} \\
\delta \mathrm{C} \\
\end{array}$ & $\begin{array}{c}{ }^{1} \mathrm{H}-\mathrm{NMR} \\
\delta \mathrm{H}\end{array}$ \\
\hline 1 & - & - \\
\hline 2 & $152.5 \mathrm{sp}^{2}$ & - \\
\hline 3 & $141.1 \mathrm{sp}^{2}$ & - \\
\hline 4 & $173.9 \mathrm{sp}^{2}$ & - \\
\hline 5 & $158.7 \mathrm{sp}^{2}$ & - \\
\hline 6 & $95.7 \mathrm{sp}^{2}$ & $6.343-6.348 \mathrm{~d}$ \\
\hline 7 & $163.8 \mathrm{sp}^{2}$ & - \\
\hline 8 & $92.3 \mathrm{sp}^{2}$ & $6.502-6.508 d$ \\
\hline 9 & $160.9 \mathrm{sp}^{2}$ & - \\
\hline 10 & $109.4 \mathrm{sp}^{2}$ & - \\
\hline 1, & $123.3 \mathrm{sp}^{2}$ & - \\
\hline 2 & $111.1 \mathrm{sp}^{2}$ & $7.715 \mathrm{~s}$ \\
\hline $3^{\prime}$ & $148.6 \mathrm{sp}^{2}$ & - \\
\hline $4^{\prime}$ & $150.7 \mathrm{sp}^{2}$ & - \\
\hline 5 & $110.7 \mathrm{sp}^{2}$ & $6.968-6.911 \mathrm{~d}$ \\
\hline 6 & $121.5 \mathrm{sp}^{2}$ & $7.697-7.715 \mathrm{~d}$ \\
\hline \multirow[t]{5}{*}{$5 \mathrm{X}-\mathrm{OCH}_{3}$} & $55.7 \mathrm{sp}^{3}$ & $3.847-3.989 \mathrm{~m}$ \\
\hline & $55.9 \mathrm{sp}^{3}$ & \\
\hline & $56.0 \mathrm{sp}^{3}$ & \\
\hline & $56.3 \mathrm{sp}^{3}$ & \\
\hline & $59.9 \mathrm{sp}^{3}$ & \\
\hline
\end{tabular}

2.2. Adipogenesis in Mouse 3T3-L1 Preadipocytes and the Effects of PMQ on Cytotoxicity and Lipid Content in Maturate Adipocyte

Preadipocytes were cultured in medium until they reached confluency and were induced to differentiate for 10 days. Figure 2A illustrates the process during which mouse 3T3-L1 preadipocytes differentiated into mature adipocytes. Images showed cells stained by Oil Red $\mathrm{O}$ at day 0, 4, 8, 10. At day 10, cells were incubated with various concentrations of PMQ for 24 hours. We did not find any detrimental effect of PMQ on cell viability at concentrations ranging from 0.1 to $10 \mu \mathrm{M}$ when incubating cells for 24 hours (P $>0.05 v s$. vehicle) (Figure 2B). PMQ also did not show any effects on lipid content in maturate adipocytes $(\mathrm{P}>0.05$ vs. vehicle) (Figure $2 \mathrm{C})$. 
Figure 2. Representative morphological images of lipid uptake in cells stained by Oil Red $\mathrm{O}$ at day $0,4,8,10$ (panel A). Cells were induced to differentiate as described in the Experimental section. Panel (B) shows that incubating cells with PMQ for 24 hours did not exhibit any detrimental effect on cell viability at concentrations ranging from 0.1 to $10 \mu \mathrm{M}$ on day 10 .

A

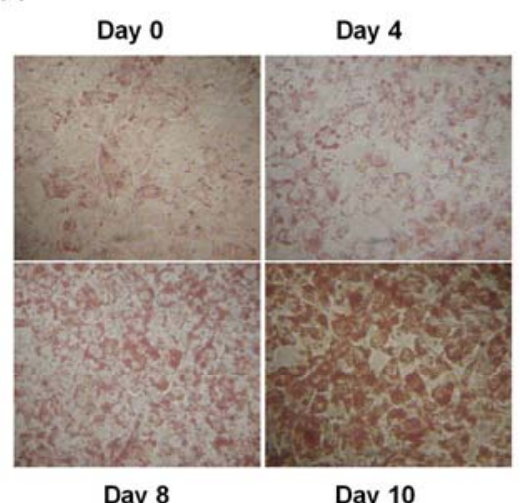

Day 8
B

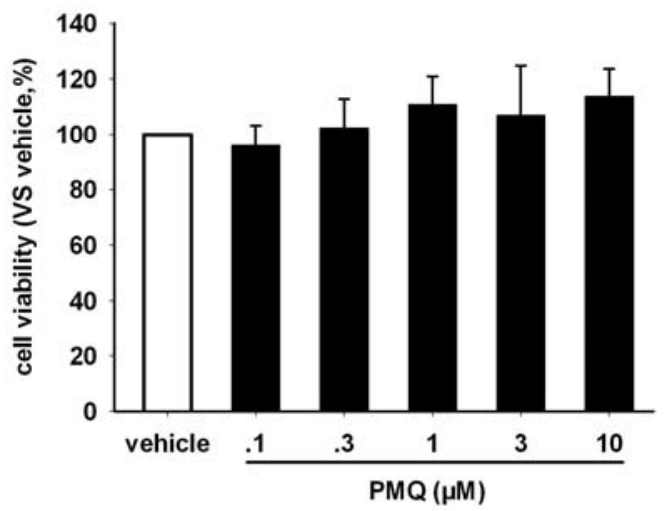

C

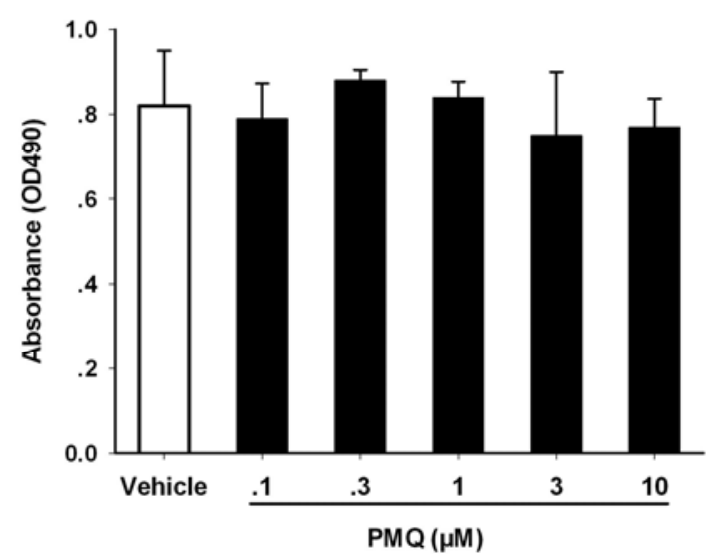

Values are expressed as means $\pm \mathrm{SD}, \mathrm{n}=6$. Panel (C) shows the effect of of PMQ on lipid content in maturate adipocytes. Differentiated 3T3-L1 adipocytes were treated with $0.1 \%$ DMSO, 0.1, 0.3, 1, 3, $10 \mu \mathrm{M}$ PMQ for 24 hours. Then cells were stained by Oil Red O. After washing, Oil Red O was extracted by isopropanol and its optical density was monitored spectrophotometrically at 490 $\mathrm{nm}$. Values are expressed as means \pm SD. $\mathrm{n}=6$ for each group.

\subsection{Effect of PMQ on Adiponectin Expression in 3T3-L1 Adipocytes}

Figures 3 show the effects of PMQ on adiponectin mRNA and protein expressions in differentiated 3T3-L1 adipocytes. We found that PMQ increased adiponectin mRNA expression in a time-dependent manner (Figure 3A). This increase started at 6 hours after PMQ treatment and reached a peak level at 24 hours. Western blot analysis with an anti-adiponectin antibody revealed that the level of adiponectin protein significantly increased at 12 hours, but not at 3 or 6 hours after PMQ treatment, compared to 0 hours controls (Figure 3B). Figure 3C showed representative RT-PCR results of differentiated 3T3-L1 cells treated with various concentrations of PMQ $(0.1,0.3,1,3$ and $10 \mu \mathrm{M})$ for 24 hours, with $0.1 \%$ DMSO treated cells as controls. It was found that PMQ increased adiponectin mRNA $(\mathrm{P}<0.05)$ expression at the concentrations of 1,3 and $10 \mu \mathrm{M}$, but not at 0.1 and $0.3 \mu \mathrm{M}$ (Figure 3C). Results 
from Western blot analysis also confirmed the dose-dependent change in adiponectin protein expression after PMQ treatment (Figure 3D).

Figure 3. Effects of PMQ on adiponectin mRNA and protein expression in 3T3-L1 adipocytes. A. RT-PCR images and semi-quantatative values of adiponectin mRNA level in 3T3-L1 adipocytes treated with PMQ $(3 \mu \mathrm{M})$ for $0,3,6,12,24,48$ hours. B. Western blot images and semi-quantatative values of adiponectin protein level in 3T3-L1 adipocytes. C. RT-PCR images and semi-quantatative values of adiponectin mRNA level in 3T3-L1 adipocytes treated with different concentrations of PMQ or vehicle for 24 hours.

D. Western blot images and semi-quantatative value of adiponectin protein level in 3T3-L1 adipocytes.

A

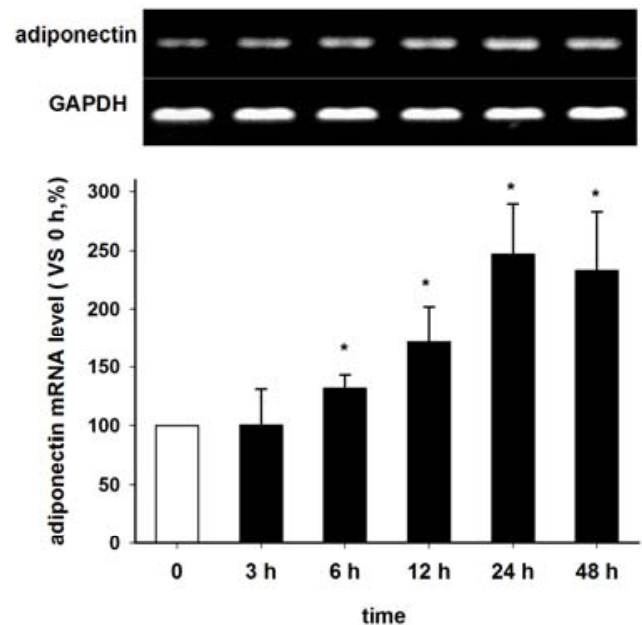

C
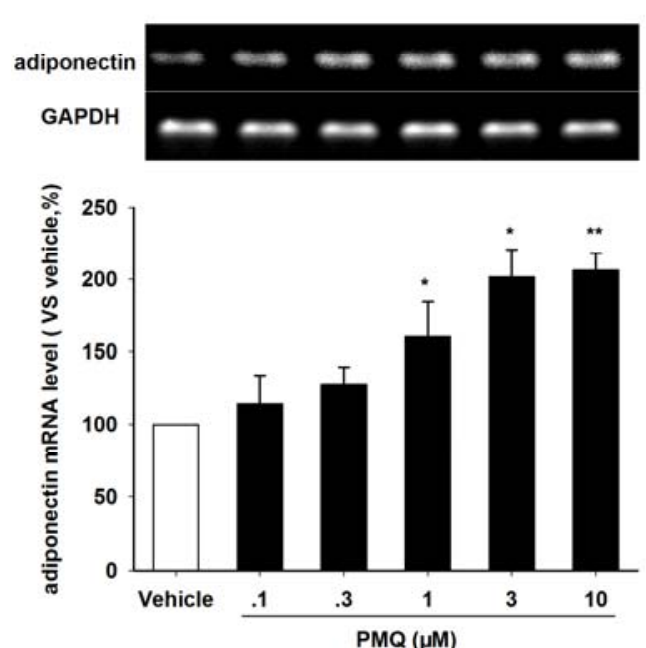

B

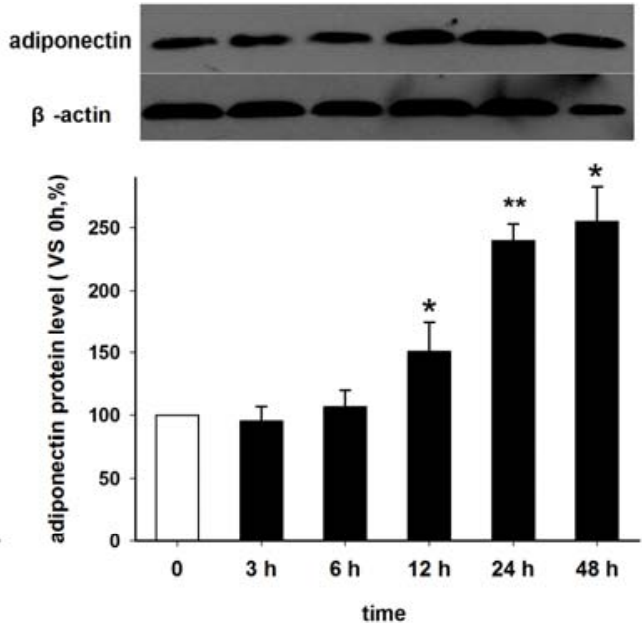

D
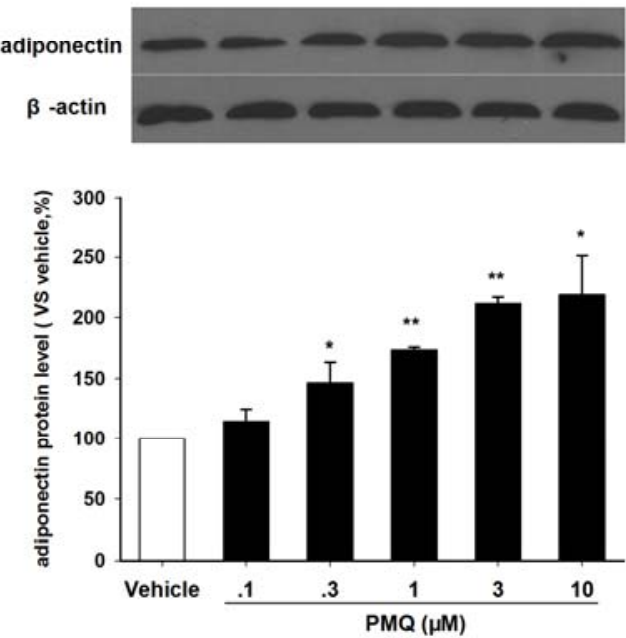

Values are expressed as means \pm SD. $\mathrm{n}=3$ for each group, ${ }^{*} P<0.05$ and $* * P<0.01 v s$. vehicle group.

\subsection{PMQ Regulates Adiponectin Expression via PPAR Pathway}

PPAR $\gamma$ is a pivotal modulator for adiponectin production in adipocytes. In the current study, we investigated whether PPAR $\gamma$ pathway were involved in the effect of PMQ on adiponectin regulation in 
3T3-L1 adipocytes. RT-PCR and Western blot analysis revealed that PMQ significantly increased the PPAR $\gamma$ mRNA and protein expressions in adipocytes at concentrations above $1 \mu \mathrm{M}$ (Figure 4).

Figure 4. Effects of PMQ on PPAR $\gamma$ mRNA and protein expression in 3T3-L1 adipocytes. A. RT-PCR images and semi-quantatative values of PPAR $\gamma$ in 3T3-L1 adipocytes treated with different concentrations of PMQ or vehicle. B. Western blot images and semiquantatative values of PPAR $\gamma$ protein level in 3T3-L1 adipocytes.

A
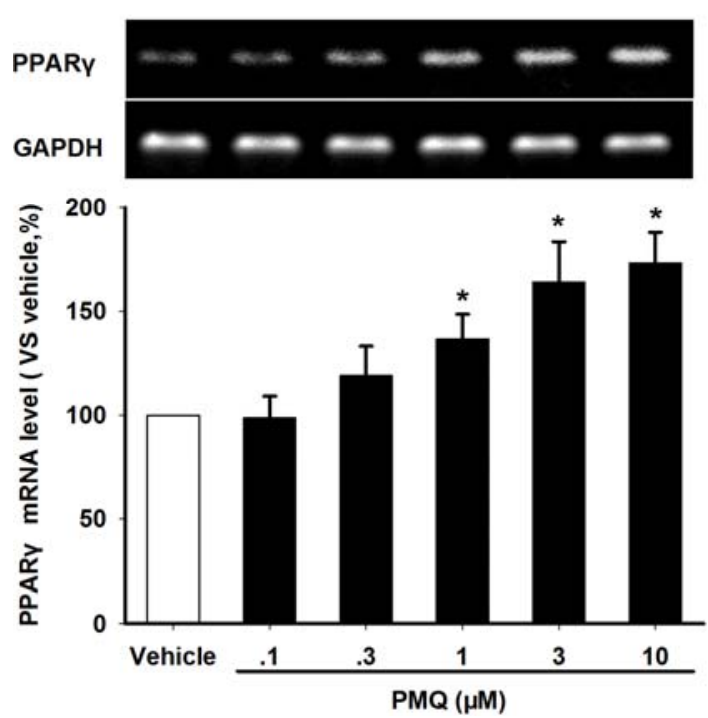

B
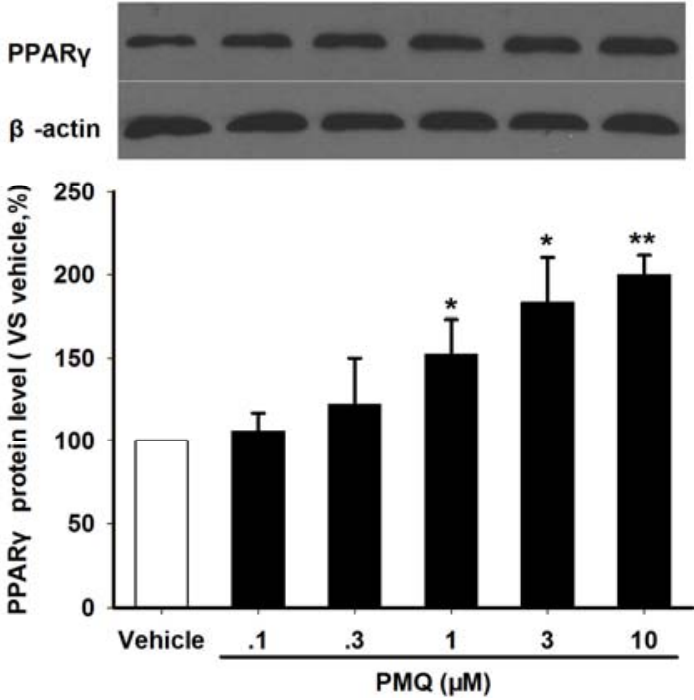

Values are expressed as means $\pm \mathrm{SD} . \mathrm{n}=3, * P<0.05$ and $* * P<0.01 v$ s. vehicle group.

Figure 5. Effects of PPAR $\gamma$ inhibitor GW9662 on PMQ-induced adiponectin expression in 3T3-L1 adipocytes. A. RT-PCR images and semi-quantatative values of adiponectin in 3T3-L1 adipocytes treated with PMQ $(3 \mu \mathrm{M})$, either with or without GW9662 (10 $\mu \mathrm{M}$.). B. Western blot images and semi-quantatative values of adiponectin protein level in 3T3-L1 adipocytes.

A
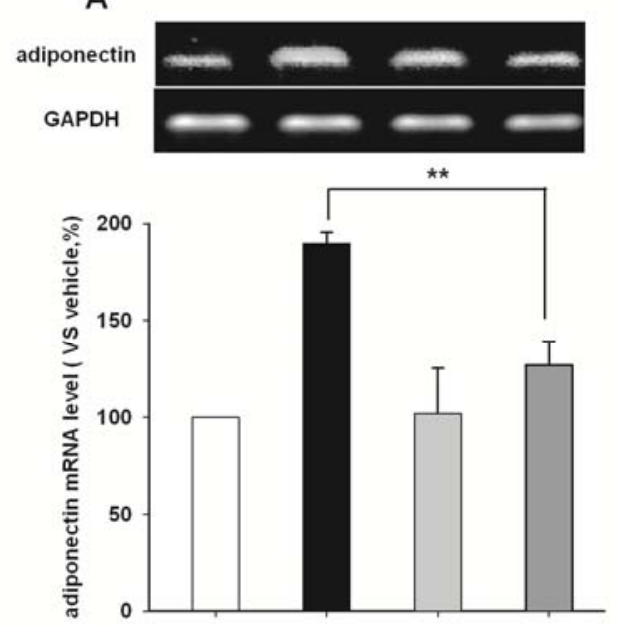

PMQ $(3 \mu \mathrm{M})$

GW9662 (10 $\mu \mathrm{M})$
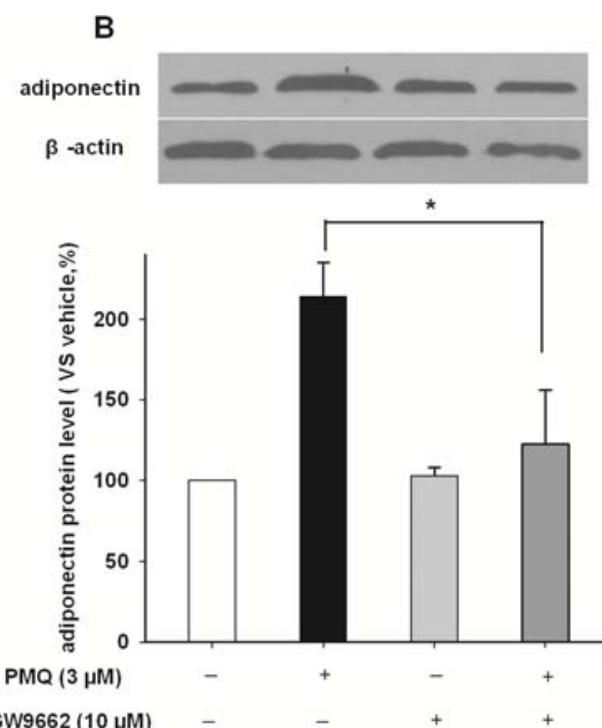

Values are expressed as means $\pm \mathrm{SD} . \mathrm{n}=3$ for each group. ${ }^{*} P<0.05$ and $* * P<0.01$ vs. PMQ treated group. 
GW9662, an inhibitor of PPAR $\gamma$, was applied in order to corroborate this observation. Figure 5 shows the mRNA and protein levels of adiponectin in 3T3-L1 adipocytes treated with vehicle, PMQ, GW9662 and GW9662 + PMQ. We showed that treating cells with $10 \mu \mathrm{M}$ GW9662 alone had no effect on adiponectin expression. However, GW9662 could significantly attenuate PMQ-induced increase of adiponectin in mRNA and protein levels (Figure 5). These results indicated that PPAR $\gamma$ pathway mediates the increase of adiponectin expression induced by PMQ.

\subsection{Effects of PMQ on Expression and Secretion of TNF- $\alpha$ and $I L-6$}

Both TNF- $\alpha$ and IL-6 are negative regulators of adiponectin expression [26,27]. Here we investigated whether PMQ also modulated the expressions of TNF- $\alpha$ and IL-6 in 3T3-L1 adipocytes. RT-PCR analysis revealed that PMQ decreased mRNA expression of TNF- $\alpha$ and IL-6 in a concentration-dependent manner, with the peak change at 3 and $10 \mu \mathrm{M}$ (Figures 6A and B). Results from ELISA detection also showed that secretion of TNF- $\alpha$ and IL- 6 in culture medium decreased significantly in cells treated with PMQ. These data suggested that TNF- $\alpha$ and IL- 6 were also involved in PMQ-induced adiponectin expression (Figures 6C and D).

Figure 6. Effects of PMQ on TNF- $\alpha$ and IL-6 mRNA expression and secretion in 3T3-L1 adipocytes. A. RT-PCR images and semi-quantatative values of TNF- $\alpha$ in 3T3-L1 adipocytes treated with different concentrations of PMQ or vehicle. B. RT-PCR images and semi-quantatative values of IL- 6 . Values are expressed as means \pm SD. $n=3$ for each group. ${ }^{*} P<0.05,{ }^{*} P<0.01$ vs. vehicle. C. Quantitative value of TNF- $\alpha$ secretion in culture medium by ELISA kits. D. IL-6 secretion in culture medium. Data are expressed as $\%$ (means $\pm \mathrm{SD}$ ) of three separate samples each performed in duplicate. $\mathrm{n}=3$ for each group, $* P<0.05$ vs. vehicle group.

A
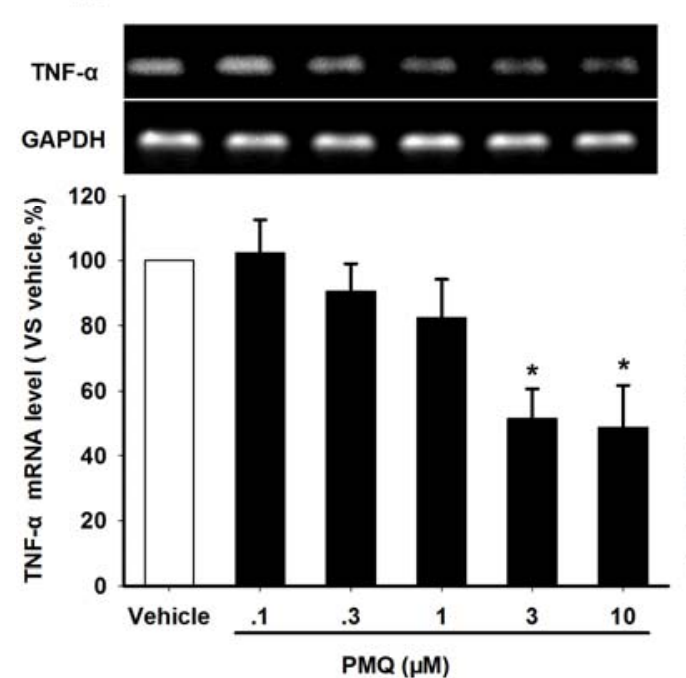

B

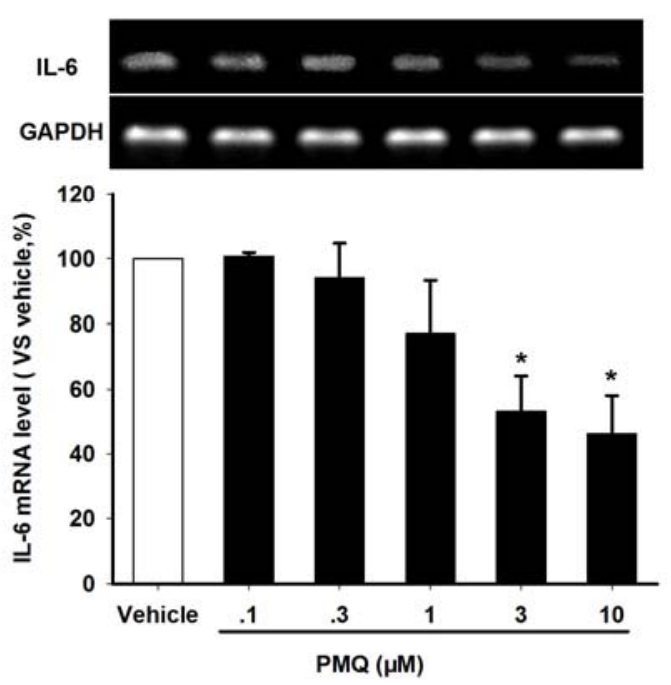


Figure 6. Cont.
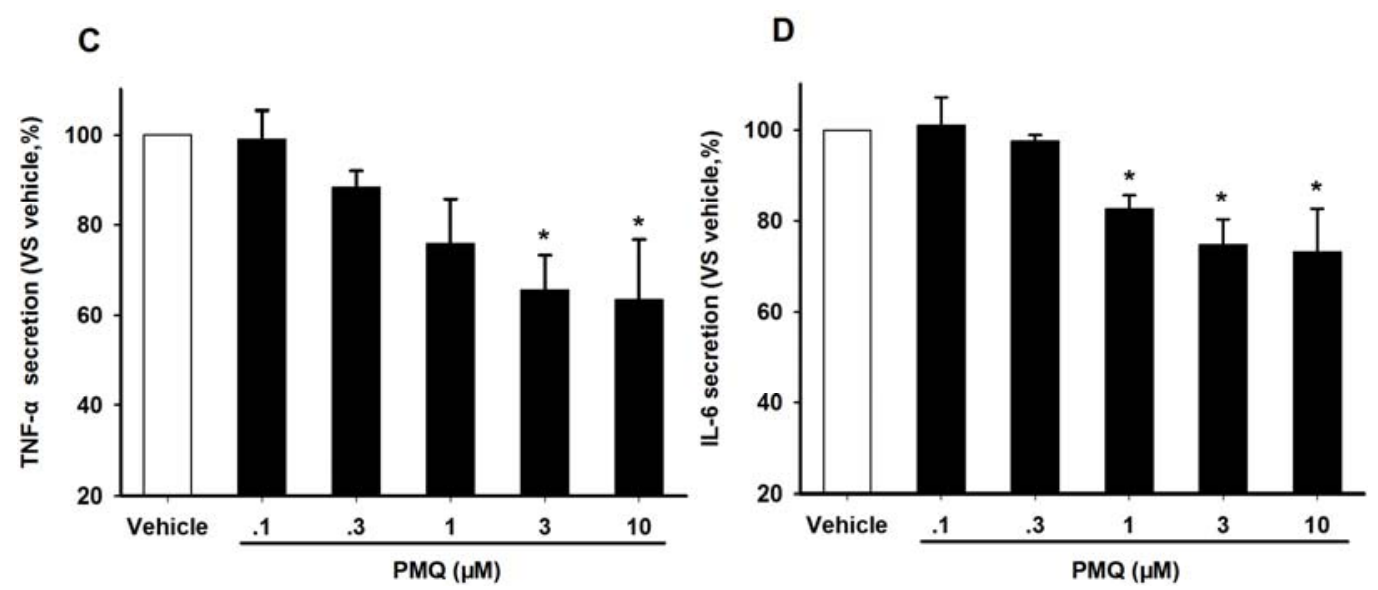

In the present study, we have demonstrated that the synthetic polymethoxylated flavonoid pentamethylquercetin (PMQ) increased adiponectin expression in differentiated 3T3-L1 adipocytes in time- and dose-dependent manners. This effect is mediated by PPAR $\gamma$ pathway because blockade of PPAR $\gamma$ by GW9662 eliminates PMQ-induced increase of adiponectin production. Furthermore, TNF- $\alpha$ and IL- 6 are also involved in PMQ-mediated up-regulation of adiponectin expression. Considering the important role of adiponectin in energy metabolism, we postulate that PMQ treatment may benefit obesity, insulin resistance, type 2 diabetes and other related metabolic diseases.

Obesity is a pandemic health problem in both developed and developing countries, which increases the risks of many common diseases, including coronary artery disease (CAD), type 2 diabetes, hypertension, gall bladder disease, and osteoarthritis [28]. Plasma adiponectin is found to be lower in obese human subjects, and reducing body weight is helpful for improving plasma adiponectin level $[11,29]$. Furthermore, the steady state mRNA of adiponectin was found to be down-regulated in ob/ob mice, suggesting the relationship between obesity and adiponectin expression [4]. Correspondingly, deletion of the mouse adiponectin gene, which induces low plasma adiponectin levels, is associated with metabolic syndrome including insulin-resistant diabetes and atherosclerotic disease [30]. Considering its extensive beneficial effects in diabetes, atherosclerotic, inflammation etc, adiponectin is deemed as a new target for treatment of metabolic syndrome. Some pharmaceutical companies have attempted syntheses of adiponectin, however, no synthetic adiponectin with in vivo bioactivity has been obtained so far. Therefore, it is of great clinical significance to search a new medicine which can stimulate the production of endogenous adiponectin. In this study, we show that polymethoxylated flavonoid pentamethylquercetin (PMQ) increase adiponectin mRNA expression and intracellular content in 3T3-L1 adipocytes, suggesting that PMQ could be a potential candidate for the treatment of obesity, metabolic syndrome, and type 2 diabetes.

PPAR $\gamma$ is a type II nuclear receptor that in humans is encoded by the PPAR $\gamma$ gene and plays a significant role in mediating insulin sensitivity [31]. It regulates fatty acid storage and glucose metabolism by regulating the transcription of many adipocyte-specific genes to stimulate lipid uptake and adipogenesis in fat cells. A large body of evidence confirms that PPAR $\gamma$, mainly expressed in adipose tissue, is a positive regulator of adiponectin gene expression. For instance, adipose-tissuespecific deletion of the PPAR $\gamma$ gene exhibits a decay of plasma adiponectin levels in mice [32]. 
Thiazolidinediones (TZDs), a well-known PPAR $\gamma$ agonist, stimulates adiponectin transcription both in vitro and in vivo [33,34]. In addition, both human [35] and mouse [36] adiponectin promoters contain a putative PPAR-responsive element (PPRE) and point mutations at this site lead to reduced basal and TZD-induced adiponectin promoter transactivation [35]. These suggest that PPAR $\gamma$ may enhance cellular adiponectin level by acting directly on its promoter. Herein, for the first time, we report that PMQ enhances PPAR $\gamma$ mRNA and protein levels, and PPAR $\gamma$ antagonist GW9662 abolishs the increase of adiponectin mRNA and protein level induced by PMQ. Although the exact mechanism through which PMQ modulates PPAR $\gamma$ remains unknown, these data still strongly suggest that PMQ regulates adiponectin production via a PPAR $\gamma$-dependent manner.

TNF- $\alpha$ and IL-6 are negative regulators of adiponectin expression. Serum concentration of IL-6 is elevated in insulin-resistant states such as obesity [37-39], impaired glucose tolerance [40] and type 2 diabetes [41,42]. Furthermore, IL-6 treatment suppresses mRNA levels and secretion of adiponectin in 3T3-L1 adipocytes [26], suggesting a negative role of IL-6 in the modulation of adiponectin levels and insulin sensitivity. Previous studies have shown that TNF- $\alpha$ down-regulates adiponectin gene expression in adipocytes by suppressing the expression of activators involved in promoting adiponectin gene expression, such as PPAR $\gamma$ [43], C/EBP [44,45]. This suppressive effect of TNF- $\alpha$ on adiponectin transcription may be mediated by JNK (c-Jun N-terminal kinase), which has been shown to phosphorylate PPAR $\gamma$ and decrease its DNA-binding activity $[27,46]$. Our present study showed that PMQ treatment significantly decreased TNF- $\alpha$ and IL-6 mRNA expressions and secretions in 3T3-L1 adipocytes, suggested that TNF- $\alpha$ and IL-6 may be involved in PMQ-induced adiponectin expression. As mentioned above that TNF- $\alpha$ suppresses the expression of PPAR $\gamma$, it suggests that PMQ might enhance adiponectin expression through decreasing the repressive effect of TNF- $\alpha$ on PPAR $\gamma$ pathway.

\section{Experimental}

\subsection{Chemicals}

Quercetin was obtained from Sewoer Industry and Trade Co., Ltd. (Hangzhou, China). Acetone, sodium hydroxide and anhydrous potassium were obtained from Sinopharm Chemical Reagent Co., Ltd. (Beijing, China). Dimethyl sulfate was obtained from Kelong Chemical Reagent Factory (Chengdu, China). Isobutyl-3-methylxanthine (IBMX), GW9662, wortmannin, dexamethasone, insulin and Oil Red O were obtained from Sigma-Aldrich Chemical Co. (St Louis, MO, USA). Dulbecco's modified Eagle's medium (DMEM) was purchased from Gibco (Invitrogen, Carlsbad, CA, USA) and fetal bovine serum (FBS) was purchased from Sijiqing (Hangzhou, China). Anti-PPAR $\gamma$ rabbit IgG , anti- $\beta$-actin mouse IgG and anti-adiponectin goat IgG were obtained from Santa Cruz Biotechnologies (Santa Cruz, CA, USA). HRP-linked anti-rabbit IgG, anti-mouse IgG and anti-goat IgG were obtained from Pierce (Thermo Scientific, Rockford, IL, USA). ELISA Kits for TNF- $\alpha$ and IL-6 were obtained from R\&D Systems (Minneapolis, MN, USA).

\subsection{Preparation of Pentamethylquercetin}

Firstly, we converted quercetin into 3,7,3',4'-tetramethylquercetin by heating to $50{ }^{\circ} \mathrm{C}$ with acetone, dimethyl sulfate and anhydrous potassium carbonate for 7 hours. Pentamethylquercetin (PMQ) is 
obtained through the agency of additional dimethyl sulfate and sodium hydroxide added after 2 hours. The structure of the end product was confirmed by mass spectrometry, ${ }^{1} \mathrm{H}-\mathrm{NMR}$ and ${ }^{13} \mathrm{C}-\mathrm{NMR}$. The purity of PMQ was examined by high performance liquid chromatography and reached $99.5 \%$ after being recrystallized twice from anhydrous alcohol.

\subsection{Cell Culture and Treatment}

Mouse 3T3-L1 preadipocytes from American Type Culture Collection (Manassas, VA, USA), were cultured in DMEM containing $25 \mathrm{mM}$ glucose supplemented with $10 \%$ bovine serum at $37{ }^{\circ} \mathrm{C}$ in a humidified atmosphere with $5 \% \mathrm{CO}_{2}$. Cells were subcultured every 3-4 days at approximately $90 \%$ confluence and cells were plated at a density that allowed them to reach confluence in 2 days. Completely confluent plates were incubated in DMEM containing 10\% FBS with $0.5 \mu \mathrm{M}$ 3-isobutyl-1methylxanthine (IBMX), $0.25 \mu \mathrm{M}$ dexamethasone and $10 \mu \mathrm{g} / \mathrm{mL}$ insulin. Two days after incubation, the medium was replaced with DMEM containing $10 \mu \mathrm{g} / \mathrm{ml}$ insulin. Thereafter, cells were maintained in the original propagation DMEM with medium changes every 2-3 days, the differentiation was completed at day 10. At day 10, cells were incubated with various concentrations of PMQ or vehicle for 24 hours. 3T3-L1 cells differentiated for 10 days were incubated for 24 hours with PMQ (3 $\mu$ M.), either with or without GW9662 (10 $\mu \mathrm{M}$.).

\subsection{Oil Red O Staining}

Adipocyte differentiation was monitored by measurement of lipid accumulation through staining of neutral fats and cholesterol esters with Oil Red O. Cells were fixed with 4\% formalin for 5 min, and stained for $10 \mathrm{~min}$ in freshly diluted Oil Red $\mathrm{O}$ solution $(0.5 \%)$. After washing, Oil Red $\mathrm{O}$ was extracted by isopropanol and its optical density was monitored spectrophotometrically at $490 \mathrm{~nm}$.

\subsection{Cell Viability Assay}

Cell viability was determined by the 3-(4,5-dimethylthiazol-2-yl)-2,5-diphenyltetrazolium bromide (MTT) assay. 3T3-L1 cells were plated into 96-well until they reached confluency and quiescent. Then the cells were induced to differentiate for 10 days. The maturate adipocytes were switched to a culture medium containing PMQ for $24 \mathrm{~h}$ and then PBS-buffered MTT $(20 \mu \mathrm{L}, 5 \mathrm{mg} / \mathrm{mL})$ solution was added to each well and the plates were incubated at $37^{\circ} \mathrm{C}$ for additional $4 \mathrm{~h}$. The medium was then removed, and $100 \mu \mathrm{L} /$ well DMSO was applied to each well to dissolve the purple formazan crystals. The plates were read (wavelengths: test, $492 \mathrm{~nm}$; reference, 570, $630 \mathrm{~nm}$ ) using a microplate spectrophotometer (Tecan, Genois Ltd, Männedorf, Switzerland). Results were standardized using vehicle group values.

\subsection{Reverse Transcription-Polymerase Chain Reaction}

Total RNA of 3T3-L1 cells was extracted using Trizol reagent (Invitrogen) following the manufacturer's instruction. Reverse transcription (RT) was performed with the RT system (Promega) protocol in a $50 \mu \mathrm{L}$ reaction mixture using oligo $(\mathrm{dT}) 18$ primers. After the RT procedure, the reaction mixture (cDNA) was used for polymerase chain reaction (PCR). Primers of corresponding genes are shown in Table 2. The reaction was conducted with the following protocol: initial denaturing of the 
template for 5 minutes at $94{ }^{\circ} \mathrm{C}$ followed by 40 repeating cycles of denaturing for 30 seconds at $94{ }^{\circ} \mathrm{C}$, annealing for 30 seconds at $50-63{ }^{\circ} \mathrm{C}$, extension for 1 minute at $72{ }^{\circ} \mathrm{C}$, and a final elongation at $72{ }^{\circ} \mathrm{C}$ for 10 minutes. The PCR products were size-fractionated by $2.5 \%$ agarose gel electrophoresis and visualized by SYBR Green I (Solarbio) staining.

Table 2. Mouse gene-specific primers for RT-PCR.

\begin{tabular}{|c|c|c|c|}
\hline Gene & Sequences $\left(5^{\prime}-3^{\prime}\right)$ & Accession No & Length (bp) \\
\hline PPAR $\gamma$ & $\begin{array}{l}\text { Forward: ACTGCCTATGAGCACTTCAC } \\
\text { Reverse: CAATCGGATGGTTCTTCGGA }\end{array}$ & NM_011146 & 448 \\
\hline Adiponectin & $\begin{array}{l}\text { Forward: } \\
\text { GGGTGAGACAGGAGATGTTGGAATG } \\
\text { Reverse: } \\
\text { GCCAGTAAATGTAGAGTCGTTGACG }\end{array}$ & NM_009605 & 478 \\
\hline IL-6 & $\begin{array}{l}\text { Forward: AGTTGCCTTCTTGGGACTGA } \\
\text { Reverse: GCCACTCCTTCTGTGACTCC } \\
\text { Forward: }\end{array}$ & NM_031168 & 521 \\
\hline TNF- $\alpha$ & $\begin{array}{l}\text { TGGAGTCATTGCTCTGTGAAGGGA } \\
\text { Reverse: } \\
\text { AGTCCTTGATGGTGGTGCATGAGA }\end{array}$ & NM_013693 & 250 \\
\hline GAPDH & $\begin{array}{l}\text { Forward: } \\
\text { GACAAAATGGTGAAGGTCGGTG } \\
\text { Reverse: TGATGTTAGTGGGGTCTCGCTC }\end{array}$ & NM_008084 & 256 \\
\hline
\end{tabular}

\subsection{Western Blotting}

Cells were harvested and lysed in RIPA buffer containing $150 \mathrm{mM} \mathrm{NaCl}, 1 \% \mathrm{NP}-40,0.5 \%$ sodium deoxycholate, $0.1 \%$ sodium dodecyl sulfate (SDS), $50 \mathrm{mM}$ Tris- $\mathrm{HCl}$ (pH 7.4), $50 \mathrm{mM}$ glycerophosphate, $20 \mathrm{mM} \mathrm{NaF}, 20 \mathrm{mM}$ EGTA, $1 \mathrm{mM}$ DTT, $1 \mathrm{mM} \mathrm{Na} \mathrm{VO}_{4}, 1 \mathrm{mM}$ phenylmethylsulfonyl fluoride, and protease inhibitors. Total cell proteins were separated by $12 \%$ SDS-polyacrylamide gel electrophoresis, transferred to a polyvinylidene fluoride membrane, and then hybridized with primary antibodies (diluted 1:400-1,000) overnight at $4{ }^{\circ} \mathrm{C}$. After incubation with horseradish-peroxidase-conjugated secondary antibody (diluted 1:3,000) for $1 \mathrm{~h}$ at room temperature, immunoreactive proteins were visualized using an enhanced chemiluminescent reagent (Amersham Pharmacia Biotech, Piscataway, NJ, USA).

\subsection{ELISIA}

Secretion of TNF- $\alpha$ and IL-6 was determined by the ELISA Quantikine Mouse TNF- $\alpha$ and IL-6 Immunoassay (R\&D Systems, Minneapolis, MN), according to the manufacturer's instruction.

\subsection{Statistical Analysis}

Data are expressed as means \pm SD. One-way ANOVA followed by Student's two-tailed unpaired $t$-test was used for the statistical analysis by SPSS 11.0 software. Values of $\mathrm{P}<0.05$ were considered to indicate statistical significance. 


\section{Conclusions}

The data herein presented demonstrates that pentamethylquercetin (PMQ), a synthetic polymethoxylated flavonoid, improved adiponectin mRNA expression and protein levels in 3T3-L1 adipocytes. This effect is related to enhanced PPAR $\gamma$ function and down-regulated TNF- $\alpha$ and IL-6. Our study raises a novel finding that PMQ could be a promising new candidate for the treatment of metabolic diseases in the future.

\section{Acknowledgements}

This study was supported by grants from Natural Science Foundation of China (no. 30772575) .We thank GuiRong Li for the helpful comments on the manuscript and Yan $\mathrm{Hu}$ for the excellent technical assistance.

\section{References and Notes}

1. Haslam, D.W.; James, W.P. Obesity. Lancet 2005, 366, 1197-1209.

2. Szmitko, P.E.; Teoh, H.; Stewart, D.J.; Verma, S. Adiponectin and cardiovascular disease: State of the art? Am. J. Physiol. Heart Circ. Physiol. 2007, 292, H1655-H1663.

3. Scherer, P.E.; Williams, S.; Fogliano, M.; Baldini, G.; Lodish, H.F. A novel serum protein similar to C1q, produced exclusively in adipocytes. J. Biol. Chem. 1995, 270, 26746-26749.

4. Hu, E.; Liang, P.; Spiegelman, B.M. AdipoQ is a novel adipose-specific gene dysregulated in obesity. J. Biol. Chem. 1996, 271, 10697-10703.

5. Lara-Castro, C.; Fu, Y.; Chung, B.H.; Garvey, W.T. Adiponectin and the metabolic syndrome: Mechanisms mediating risk for metabolic and cardiovascular disease. Curr. Opin. Lipidol. 2007, 18, 263-270.

6. Oh, D.K.; Ciaraldi, T.; Henry, R.R. Adiponectin in health and disease. Diabetes Obes. Metab. 2007, 9, 282-289.

7. Matsuda, M.; Shimomura, I.; Sata, M.; Arita, Y.; Nishida, M.; Maeda, N.; Kumada, M.; Okamoto, Y.; Nagaretani, H.; Nishizawa, H.; et al. Role of adiponectin in preventing vascular stenosis. The missing link of adipo-vascular axis. J. Biol. Chem. 2002, 277, 37487-37491.

8. Ouchi, N.; Kihara, S.; Arita, Y.; Nishida, M.; Matsuyama, A.; Okamoto, Y.; Ishigami, M.; Kuriyama, H.; Kishida, K.; Nishizawa, H.; et al. Adipocyte-derived plasma protein, adiponectin, suppresses lipid accumulation and class A scavenger receptor expression in human monocytederived macrophages. Circulation 2001, 103, 1057-1063.

9. Ouchi, N.; Kihara, S.; Arita, Y.; Okamoto, Y.; Maeda, K.; Kuriyama, H.; Hotta, K.; Nishida, M.; Takahashi, M.; Muraguchi, M.; et al. Adiponectin, an adipocyte-derived plasma protein, inhibits endothelial NF-kappaB signaling through a cAMP-dependent pathway. Circulation 2000, 102, 1296-1301.

10. Ouchi, N.; Kihara, S.; Funahashi, T.; Nakamura, T.; Nishida, M.; Kumada, M.; Okamoto, Y.; Ohashi, K.; Nagaretani, H.; Kishida, K.; et al. Reciprocal association of C-reactive protein with adiponectin in blood stream and adipose tissue. Circulation 2003, 107, 671-674. 
11. Arita, Y.; Kihara, S.; Ouchi, N.; Takahashi, M.; Maeda, K.; Miyagawa, J.; Hotta, K.; Shimomura, I.; Nakamura, T.; Miyaoka, K.; et al. Paradoxical decrease of an adipose-specific protein, adiponectin, in obesity. Biochem. Biophys. Res. Commun. 1999, 257, 79-83.

12. Matsubara, M.; Maruoka, S.; Katayose, S. Decreased plasma adiponectin concentrations in women with dyslipidemia. J. Clin. Endocrinol. Metab. 2002, 87, 2764-2769.

13. Hotta, K.; Funahashi, T.; Arita, Y.; Takahashi, M.; Matsuda, M.; Okamoto, Y.; Iwahashi, H.; Kuriyama, H.; Ouchi, N.; Maeda, K.; et al. Plasma concentrations of a novel, adipose-specific protein, adiponectin, in type 2 diabetic patients. Arterioscler Thromb. Vasc. Biol. 2000, 20, 1595-1599.

14. Serafini, M.; Peluso, I.; Raguzzini, A. Flavonoids as anti-inflammatory agents. Proc. Nutr. Soc. 2006, 69, 273-278.

15. Knekt, P.; Kumpulainen, J.; Jarvinen, R.; Rissanen, H.; Heliovaara, M.; Reunanen, A.; Hakulinen, T.; Aromaa, A. Flavonoid intake and risk of chronic diseases. Am. J. Clin. Nutr. 2002, $76,560-568$.

16. Hertog, M.G.; Feskens, E.J.; Hollman, P.C.; Katan, M.B.; Kromhout, D. Dietary antioxidant flavonoids and risk of coronary heart disease: The Zutphen Elderly Study. Lancet 1993, 342, 1007-1011.

17. Mink, P.J.; Scrafford, C.G.; Barraj, L.M.; Harnack, L.; Hong, C.P.; Nettleton, J.A.; Jacobs, D.R., Jr. Flavonoid intake and cardiovascular disease mortality: A prospective study in postmenopausal women. Am. J. Clin. Nutr. 2007, 85, 895-909.

18. Walle, U.K.; Walle, T. Bioavailable flavonoids: Cytochrome P450-mediated metabolism of methoxyflavones. Drug Metab. Dispos. 2007, 35, 1985-1989.

19. Li, R.W.; Theriault, A.G.; Au, K.; Douglas, T.D.; Casaschi, A.; Kurowska, E.M.; Mukherjee, R. Citrus polymethoxylated flavones improve lipid and glucose homeostasis and modulate adipocytokines in fructose-induced insulin resistant hamsters. Life Sci. 2006, 79, 365-373.

20. Liu, L.; Shan, S.; Zhang, K.; Ning, Z.Q.; Lu, X.P.; Cheng, Y.Y. Naringenin and hesperetin, two flavonoids derived from Citrus aurantium up-regulate transcription of adiponectin. Phytother. Res. 2008, 22, 1400-1403.

21. Kunimasa, K.; Kuranuki, S.; Matsuura, N.; Iwasaki, N.; Ikeda, M.; Ito, A.; Sashida, Y.; Mimaki, Y.; Yano, M.; Sato, M.; et al. Identification of nobiletin, a polymethoxyflavonoid, as an enhancer of adiponectin secretion. Bioorg. Med. Chem. Lett. 2009, 19, 2062-2064.

22. Hibasami, H.; Mitani, A.; Katsuzaki, H.; Imai, K.; Yoshioka, K.; Komiya, T. Isolation of five types of flavonol from seabuckthorn (Hippophae rhamnoides) and induction of apoptosis by some of the flavonols in human promyelotic leukemia HL-60 cells. Int. J. Mol. Med. 2005, 15, 805-809.

23. Mao, Z.; Liang, Y.; Du, X.; Sun, Z. 3,3',4',5,7-Pentamethylquercetin reduces angiotensin IIinduced cardiac hypertrophy and apoptosis in rats. Can. J. Physiol. Pharmacol. 2009, 87, 720-728.

24. Dong, H.; Gou, Y.-L.; Cao, S.-G.; Chen, S.-X.; Sim, K.-Y.; Goh, S.-H.; Kini, R.M. Eicosenones and methylated flavonols from Amomumkoenigii Phytochemistry 1999, 50, 899-902.

25. Heijnen, C.G.M.; Haenen, G.R.M.M.; Vekemansb, J.A.J.M.; Basta, A. Peroxynitrite scavenging of flavonoids: Structure activity relationship. Environ. Toxicol. Pharmacol. 2001, 10, 199-206. 
26. Fasshauer, M.; Kralisch, S.; Klier, M.; Lossner, U.; Bluher, M.; Klein, J.; Paschke, R. Adiponectin gene expression and secretion is inhibited by interleukin-6 in 3T3-L1 adipocytes. Biochem. Biophys. Res. Commun. 2003, 301, 1045-1050.

27. Kim, K.Y.; Kim, J.K.; Jeon, J.H.; Yoon, S.R.; Choi, I.; Yang, Y. c-Jun N-terminal kinase is involved in the suppression of adiponectin expression by TNF-alpha in 3T3-L1 adipocytes. Biochem. Biophys. Res. Commun. 2005, 327, 460-467.

28. Must, A.; Spadano, J.; Coakley, E.H.; Field, A.E.; Colditz, G.; Dietz, W.H. The disease burden associated with overweight and obesity. JAMA 1999, 282, 1523-1529.

29. Yang, W.S.; Lee, W.J.; Funahashi, T.; Tanaka, S.; Matsuzawa, Y.; Chao, C.L.; Chen, C.L.; Tai, T.Y.; Chuang, L.M. Weight reduction increases plasma levels of an adipose-derived antiinflammatory protein, adiponectin. J. Clin. Endocrinol. Metab. 2001, 86, 3815-3819.

30. Kondo, H.; Shimomura, I.; Matsukawa, Y.; Kumada, M.; Takahashi, M.; Matsuda, M.; Ouchi, N.; Kihara, S.; Kawamoto, T.; Sumitsuji, S.; Funahashi, T.; Matsuzawa, Y. Association of adiponectin mutation with type 2 diabetes: A candidate gene for the insulin resistance syndrome. Diabetes 2002, 51, 2325-2328.

31. Michalik, L.; Auwerx, J.; Berger, J.P.; Chatterjee, V.K.; Glass, C.K.; Gonzalez, F.J.; Grimaldi, P.A.; Kadowaki, T.; Lazar, M.A.; O'Rahilly, S.; et al. International Union of Pharmacology. LXI. Peroxisome proliferator-activated receptors. Pharmacol. Rev. 2006, 58, 726-741.

32. He, W.; Barak, Y.; Hevener, A.; Olson, P.; Liao, D.; Le, J.; Nelson, M.; Ong, E.; Olefsky, J.M.; Evans, R.M. Adipose-specific peroxisome proliferator-activated receptor gamma knockout causes insulin resistance in fat and liver but not in muscle. Proc. Natl. Acad. Sci. USA 2003, 100, 15712-15717.

33. Yu, J.G.; Javorschi, S.; Hevener, A.L.; Kruszynska, Y.T.; Norman, R.A.; Sinha, M.; Olefsky, J.M. The effect of thiazolidinediones on plasma adiponectin levels in normal, obese, and type 2 diabetic subjects. Diabetes 2002, 51, 2968-2974.

34. Kanatani, Y.; Usui, I.; Ishizuka, K.; Bukhari, A.; Fujisaka, S.; Urakaze, M.; Haruta, T.; Kishimoto, T.; Naka, T.; Kobayashi, M. Effects of pioglitazone on suppressor of cytokine signaling 3 expression: Potential mechanisms for its effects on insulin sensitivity and adiponectin expression. Diabetes 2007, 56, 795-803.

35. Iwaki, M.; Matsuda, M.; Maeda, N.; Funahashi, T.; Matsuzawa, Y.; Makishima, M.; Shimomura, I. Induction of adiponectin, a fat-derived antidiabetic and antiatherogenic factor, by nuclear receptors. Diabetes 2003, 52, 1655-1663.

36. Seo, J.B.; Moon, H.M.; Noh, M.J.; Lee, Y.S.; Jeong, H.W.; Yoo, E.J.; Kim, W.S.; Park, J.; Youn, B.S.; Kim, J.W.; et al. Adipocyte determination- and differentiation-dependent factor $1 /$ sterol regulatory element-binding protein $1 \mathrm{c}$ regulates mouse adiponectin expression. $J$. Biol. Chem. 2004, 279, 22108-22117.

37. Fernandez-Real, J.M.; Vayreda, M.; Richart, C.; Gutierrez, C.; Broch, M.; Vendrell, J.; Ricart, W. Circulating interleukin 6 levels, blood pressure, and insulin sensitivity in apparently healthy men and women. J. Clin. Endocrinol. Metab. 2001, 86, 1154-1159. 
38. Mohamed-Ali, V.; Goodrick, S.; Rawesh, A.; Katz, D.R.; Miles, J.M.; Yudkin, J.S.; Klein, S.; Coppack, S.W. Subcutaneous adipose tissue releases interleukin-6, but not tumor necrosis factoralpha, in vivo. J. Clin. Endocrinol. Metab. 1997, 82, 4196-4200.

39. Straub, R.H.; Hense, H.W.; Andus, T.; Scholmerich, J.; Riegger, G.A.; Schunkert, H. Hormone replacement therapy and interrelation between serum interleukin- 6 and body mass index in postmenopausal women: A population-based study. J. Clin. Endocrinol. Metab. 2000, 85, 1340-1344.

40. Muller, S.; Martin, S.; Koenig, W.; Hanifi-Moghaddam, P.; Rathmann, W.; Haastert, B.; Giani, G.; Illig, T.; Thorand, B.; Kolb, H. Impaired glucose tolerance is associated with increased serum concentrations of interleukin 6 and co-regulated acute-phase proteins but not TNF-alpha or its receptors. Diabetologia 2002, 45, 805-812.

41. Kado, S.; Nagase, T.; Nagata, N. Circulating levels of interleukin-6, its soluble receptor and interleukin-6/interleukin-6 receptor complexes in patients with type 2 diabetes mellitus. Acta Diabetol. 1999, 36, 67-72.

42. Pickup, J.C.; Mattock, M.B.; Chusney, G.D.; Burt, D. NIDDM as a disease of the innate immune system: Association of acute-phase reactants and interleukin-6 with metabolic syndrome X. Diabetologia 1997, 40, 1286-1292.

43. Zhang, B.; Berger, J.; Hu, E.; Szalkowski, D.; White-Carrington, S.; Spiegelman, B.M.; Moller, D.E. Negative regulation of peroxisome proliferator-activated receptor-gamma gene expression contributes to the antiadipogenic effects of tumor necrosis factor-alpha. Mol. Endocrinol. 1996, 10, 1457-1466.

44. Kita, A.; Yamasaki, H.; Kuwahara, H.; Moriuchi, A.; Fukushima, K.; Kobayashi, M.; Fukushima, T.; Takahashi, R.; Abiru, N.; Uotani, S.; Kawasaki, E.; Eguchi, K. Identification of the promoter region required for human adiponectin gene transcription: Association with CCAAT/enhancer binding protein-beta and tumor necrosis factor-alpha. Biochem. Biophys. Res. Commun. 2005, 331, 484-490.

45. Ron, D.; Brasier, A.R.; McGehee, R.E., Jr.; Habener, J.F. Tumor necrosis factor-induced reversal of adipocytic phenotype of 3T3-L1 cells is preceded by a loss of nuclear CCAAT/enhancer binding protein (C/EBP). J. Clin. Invest. 1992, 89, 223-233.

46. Lim, J.Y.; Kim, W.H.; Park, S.I. GO6976 prevents TNF-alpha-induced suppression of adiponectin expression in 3T3-L1 adipocytes: Putative involvement of protein kinase C. FEBS Lett. 2008, 582, 3473-3478.

Sample Availability: Samples of the compound PMQ is available from the authors.

(C) 2011 by the authors; licensee MDPI, Basel, Switzerland. This article is an open access article distributed under the terms and conditions of the Creative Commons Attribution license (http://creativecommons.org/licenses/by/3.0/). 